\title{
New records of association between Brachyscelus $c f$ rapacoides (Arthropoda: Amphipoda) and medusae (Cnidaria: Scyphozoa and Hydrozoa) from São Sebastião Channel, southeast Brazil
}

\author{
Francisco Alejandro Puente Tapia ${ }^{1,2 *}{ }^{\bullet}$, Rebeca Gasca $^{3}$, Gabriel Genzano ${ }^{1,2}$, Agustín Schiariti ${ }^{1,2,4}$, \\ André Carrara Morandini ${ }^{5,6}$
}

\author{
${ }^{1}$ Instituto de Investigaciones Marinas y Costeras (IIMyC), Universidad Nacional de Mar del Plata (UNMdP) \\ (Rodríguez Peña $n^{\circ}$. 4046, Mar del Plata, Buenos Aires, Argentina) \\ ${ }^{2}$ Consejo Nacional de Investigaciones Científicas y Técnicas (CONICET) \\ (Mar del Plata, Buenos Aires, Argentina) \\ ${ }^{3}$ El Colegio de la Frontera Sur (ECOSUR) \\ (Av. del Centenario Km. 5.5, Chetumal, Quintana Roo, México. C.P. 77014) \\ ${ }^{4}$ Instituto Nacional de Investigación y Desarrollo Pesquero (INIDEP) \\ (Paseo Victoria Ocampo no ${ }^{\circ}$, Escollera Norte, Mar del Plata, Buenos Aires, Argentina) \\ ${ }^{5}$ Departamento de Zoologia, Instituto de Biociências, Universidade de São Paulo \\ (Rua do Matão, trav. 14, n 321, Cidade Universitária, São Paulo, Brazil) \\ ${ }^{6}$ Centro de Biologia Marinha, Universidade de São Paulo \\ (Rod. Manoel Hypólito do Rego, km 131.5, São Sebastião, Brazil)
}

*Corresponding author: alecspuente@gmail.com

Medusae have a great diversity of associations with different crustacean groups such as Amphipoda, Cirripedia, Isopoda, Copepoda, Decapoda and Mysidacea (e.g. Moreira, 1961; Phillips et al., 1969; Bruce, 1972; Martin and Kuck, 1991; Pagès, 2000; Sorarrain et al., 2001; Browne and Kingsford, 2005; Nogueira Jr. and De Loyola e Silva, 2005; Martinelli Filho et al., 2008). Amphipoda is one of the most representative groups of marine symbiotic crustaceans, many species are associated as symbionts or parasites of other organisms including cnidarians, mollusks, other crustaceans, tunicates, as well as fishes, sea turtles, dolphins, and whales (LeCroy et al., 2009). According to Laval (1980), hyperiids represent a remarkable lineage of amphipods that are adapted to live as holoplanktonic forms that evolved from benthic ancestors, and use as a substratum, shelter and source of food other pelagic organisms, mainly gelatinous zooplankters, at least during the first part of their life cycle.

The nature of this association depends on the hyperiid species and varies according to hydrological and biological factors such as season, abundance and size of hosts, temperature, and parasite life cycle (Dittrich, 1987;1992). These interactions have been characterized with different levels of detail and reported under different terms such as

Submitted on: 30/March/2018

Approved on: 19/August/2018

http://dx.doi.org/10.1590/S1679-87592018017806603 parasitoidism, micropredation, protection, phoresis, and buoyancy (Madin and Harbison, 1977; Laval, 1980; Vader, 1984; Ohtsuka et al., 2009). The association might be of a simple guest if they feed on the material filtered by the host, or as parasitism if they feed on the host tissues. These associations may be mandatory for a number of species at a certain phase on their life-cycles and may or may not present host specificity (Lima and Valentin, 2001a). Some genera and even families appear to be restricted to associations with certain host groups (Harbison et al., 1977; Laval, 1980), but the mechanisms for host selection are diverse (Vader, 1984; Gasca et al., 2015). In general, it is assumed that most hyperiid amphipods depend on the association to complete their life cycle (Laval, 1980).

The present report is the result of a fortuitous finding of hyperiids inside different medusae species during a routine sorting of zooplankton samples. This contribution reports a previously unknown association between the hyperiid amphipod Brachyscelus cf. rapacoides Stephensen, 1925 with two jellyfish hosts from São Sebastião Channel, southeastern Brazil.

São Sebastião Channel is located between the municipality of São Sebastião and São Sebastião Island (municipality of Ilhabela) on the north coast of São Paulo state. The area presents a subtropical climate and water temperatures ranges between 15 and $20^{\circ} \mathrm{C}$ (Migotto et al., 2001). The local currents are driven by wind, usually associated with southerly cold fronts (Castro Filho, 1990). 
The genus Brachyscelus Spence Bate, 1861 is widely distributed in tropical and warm-temperate regions of the world's oceans (Zeidler, 2016). According to Madin and Harbison (1977) at least 17 species have been described in this genus (including also its junior synonym Thamyris Claus, 1879). But, only four of them were recognized as valid by Vinogradov et al. (1996), who considered B. rapacoides as a synonym of Brachyscelus rapax (Claus, 1879). Other studies resulted in the recognition of at least five species, including now B. rapacoides as valid (Zeidler, 1992;2016). The reason for the reduction of valid species is that several of them were poorly described, more than a century ago. Only through a detailed revision of the type material and the use of molecular techniques, this could be solved. It is difficult to ascertain the distribution of $B$. rapacoides because it was, for some time, considered a synonym of $B$. rapax and also due to some misidentifications. Even though, $B$. rapacoides is a relatively rare species, known from widely separated records from tropical and temperate regions worldwide (Dick, 1970). Zeidler and De Broyer (2009) recorded it also in the Southern Ocean (Antarctic), specifically from the Indian sector (South of Australia). In the Atlantic Ocean, it has been recorded from about $44^{\circ} \mathrm{N}$ to tropical regions off Africa and Brazil (up to off Florianópolis, Brazil, $27^{\circ} 50.3^{\prime} \mathrm{S}$ and $47^{\circ} 54.0^{\prime} \mathrm{W}$ ) (Lima and Valentin, 2001b). Most samples are from near-surface waters (see Zeidler and De Broyer, 2009), however, the species appear to have epipelagic to shallow-mesopelagic distribution (LeCroy et al., 2009; Zeidler, 2016).

Medusae were collected along the São Sebastião Channel on 14 November 2015 (austral spring) from two different sources: 1) standard zooplankton net trawling: three tows were carried out using a Bongo-type net $(75 \mathrm{~cm}$ mouth diameter; $500 \mu \mathrm{m}$ mesh size) operated in oblique tows performed from $\sim 7 \mathrm{~m}$ to surface for 5 to 10 minutes at about 2 knots; 2) three hauls carried out using a demersal trawl $(9.7 \mathrm{~m}$ otter trawls with 1 and $3 \mathrm{~cm}$ stretch mesh in the body and sleeve, and $25 \mathrm{~mm}$ in the cod end bar mesh) towed on the bottom for 10 minutes at a speed of 3-4 knots. In both cases, tows were carried outs during daylight. In addition, during an environmental monitoring of the study area, a single Chrysaora lactea Eschscholtz, 1829 specimen was collected from the surface, with a hand net (29 November 2015). Samples were examined in vivo under a stereomicroscope at the laboratory at the Centro de Biologia Marinha, Universidade de São Paulo (CEBIMarUSP) during the following $2 \mathrm{~h}$ while most specimens remain alive. Hyperiids were removed and isolated from the hosts tissues and preserved in $4 \%$ formaldehyde seawater solution for taxonomical identification and conservation. Taxonomic identifications of medusae followed Mianzan and Cornelius (1999) and Bouillon (1999), while of the amphipods hyperiids followed Vinogradov et al. (1996) and Zeidler (2016). The amphipods were deposited in the collection of zooplankton at El Colegio de la Frontera Sur (ECOSUR), Chetumal, Quintana Roo, Mexico (ECO-CHZ).

The total length of the hyperiids (i.e. from the front of the head, excluding the antennae, to the posterior margin of the last uropods, in $\mathrm{mm}$ ) was measured (Sheader and Evans, 1975). The total number of medusae bearing hyperiids and the number of hyperiids observed on each medusae were also recorded. Intensity of infection (number of individuals of the hyperiid in a single specimen) and intensity interval (the minimum and maximum number of hyperiid by infected specimen) were estimated following Bush et al. (1997).

Only the scyphomedusae $C$. lactea and the hydromedusae Olindias sambaquiensis Müller, 1861 were positive for hyperiid amphipod specimens, which were identified as $B$. cf. rapacoides because of the following features: 1) head pointed in males, round in females; 2 ) S5 (fifth segment) of PI (first pereopod) higher than long, with a distinct anterodistal process; 3 ) S5 and S6 of PI with large teeth mixed with smaller ones; 4) P5 S2 oval and its length is almost double of its width, S4 and S5 wider distally; 5) PVI basis width about $73 \%$ its length, basis length about $65 \%$ of the remaining segments, regular spines in anterior margin of distal third of S4 and in all anterior margin of S5 and S6; 6) PVII shorter than the remaining segments in one specimen but longer in bigger specimens; 7) telson slightly longer than wide. The analyzed specimens, however, show some differences with respect to the original description of $B$. rapacoides by Stephensen (1925), particularly in details of PI, PII, and urosome size and proportions (Vinogradov et al., 1996; Zeidler, 2016). Unfortunately, the specimens analyzed were not adults.

From ten examined amphipods found in C. lactea, seven were larval stages (pantochelis and/or protopleon), ranging between 0.45 and $0.8 \mathrm{~mm}$ total length, and three were juveniles varying between 2.50 and $6.04 \mathrm{~mm}$ total length. Two juvenile females and one juvenile male specimens were identified (see Figure 1 for $B$. cf. rapacoides development stages identified). Only one individual of the hydromedusa $O$. sambaquiensis was found with $B$. cf. rapacoides bearing only one specimen of the amphipod. This specimen of $O$. sambaquiensis was not measured and sexed, due to their further use for toxicological studies (Table 1). 


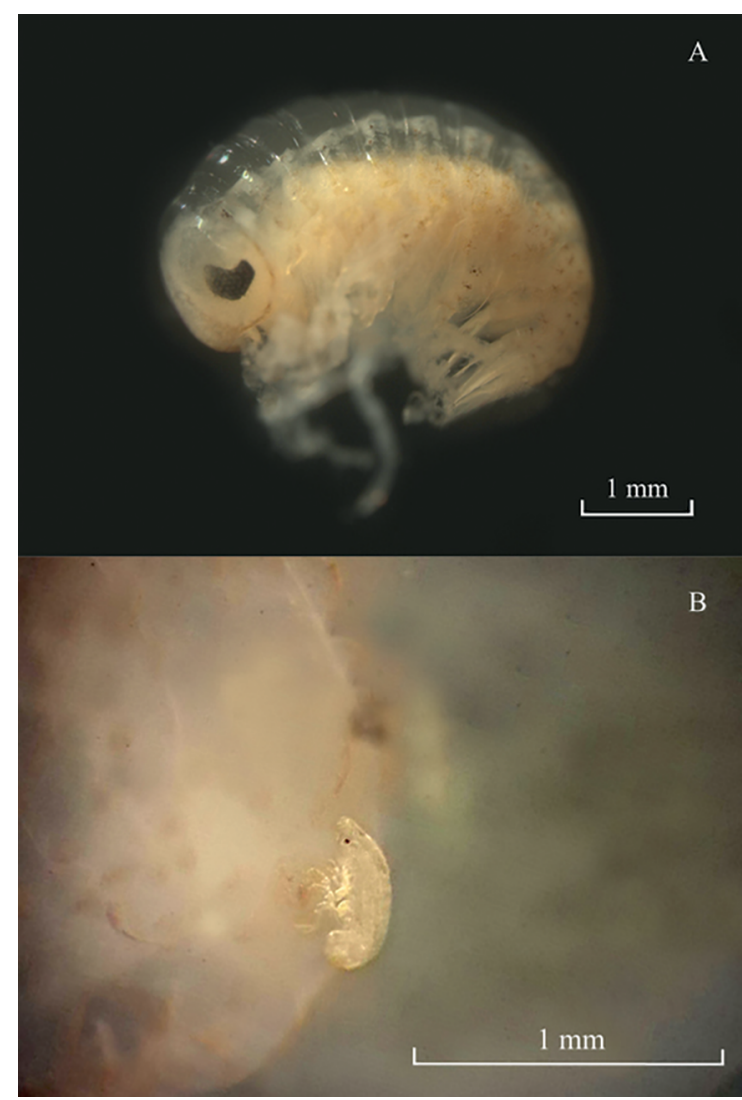

Figure 1. Brachyscelus cf. rapacoides parasitizing medusae of Chrysaora lactea from São Sebastião Channel, SE Brazil. A) Female specimen and B) larval stage.

A total of 32 individuals of $C$. lactea were collected, but hyperiids were present in only four (12.5\%). Medusae bell diameter ( $\mathrm{n}=31$; one individual could not be measured) ranged between 63 and $124 \mathrm{~mm}$, while the size of the parasitized individuals varied between 82 and $98 \mathrm{~mm}$. The maximum intensity of infection was seven, while the intensity interval ranged between 1-7 hyperiids per host.

Observations of living medusae showed that hyperiids were distributed in different parts of the host body including the gastric pouches, the gonadal zone, and the oral arms. The larval stages were found only in the gastric pouches.

Individuals of the genus Brachyscelus have been recorded from a variety of gelatinous zooplankton although most species prefer medusae as hosts (Zeidler, 2016). Particularly B. rapacoides has been recorded in the hydromedusae Aequorea sp., Orchistoma sp., and Leuckartiara sp., as well as in pteropod Diacavolinia longirostris (Lesueur, 1821) (as Cavolinia longirostris) (Harbison et al., 1977). Recently, Gasca et al. (2015) recorded an unidentifiable juvenile of this genus from the narcomedusae Solmissus incisa (Fewkes, 1886). Other congeners, like Brachyscelus crusculum Spence Bate, 1861 have been recorded in association with salps, heteropods and medusae (see Harbison et al., 1977; Laval, 1980; Gasca and Haddock, 2004), such as the hydrozoan Aequorea coerulescens (Brandt, 1835) (Gasca and Haddock, 2004).

Previous reports of associations between hyperiid amphipods and gelatinous zooplankton from the Southwestern Atlantic Ocean (Argentinean coast) include the record of Hyperoche medusarum (Krøyer, 1838) with the ctenophore Mnemiopsis leidyi A. Agassiz, 1865 (as Mnemiopsis mccradyi) (Sorarrain et al., 2001) and Hyperoche martinezii Müller, 1864) with three different ctenophores (Puente Tapia et al., 2016). In the Brazilian coast, $C$. lactea has been found in association with isopods (Nogueira Jr. and De Loyola e Silva, 2005), metacercariae Opechona sp. (Nogueira Jr. et al., 2015), and shrimps (Martinelli Filho et al., 2008), while $O$. sambaquiensis only with isopods (Nogueira Jr. and De Loyola e Silva, 2005).

Two different developmental stages (larval and juvenile phase), as well as two females and one male of $B$. cf. rapacoides, were observed in C. lactea. The presence of these stages in the same host would suggest a close dependence between the amphipod and its gelatinous host. As a platysceloidean hyperiid, B. rapacoides has reduced mouthparts, a condition that is probably related to the high degree of dependence on gelatinous zooplankton hosts; reduction is stronger in females, suggesting that females spend more time on the host than males (Zeidler, 2016). In some amphipod species, adults remain in the host together with their offspring, so the same host could be simultaneously occupied by different generations of the hyperiid (Gasca et al., 2014). According to Lima and Valentin (2001a), females are usually much more common in association, and it is believed that a number of females, once inside their hosts, may live longer in the latter than male individuals which, upon reaching the adult stage, abandon their host. Thurston (1977) remarked that the number of juveniles on a single host is markedly less than the offspring number of the hyperiid. Metz (1967) attributed this difference to the escape of hyperiids after hatching, because juveniles are capable of swimming and they start searching for a new host (Laval, 1980). The life cycles of hyperiid amphipods are both complex and poorly known; obligate parasitism for all its stages has 
Table 1. Material examined. Medusae (sex and umbrellar diameter) and hyperiid parameters (stage of development, sex, total length and ubication in the host).

\begin{tabular}{|c|c|c|c|c|c|c|c|c|}
\hline Host species & Host sex & $\begin{array}{l}\text { Umbrellar } \\
\text { diameter } \\
(\mathrm{mm})\end{array}$ & $\begin{array}{l}\text { Stage of } \\
\text { parasite }\end{array}$ & $\begin{array}{l}\text { Parasites } \\
\text { sex }\end{array}$ & $\begin{array}{l}\text { Number of } \\
\text { parasites }\end{array}$ & $\begin{array}{l}\text { Total } \\
\text { length } \\
\text { parasite } \\
(\mathrm{mm})\end{array}$ & $\begin{array}{l}\text { Host } \\
\text { area }\end{array}$ & Remarks \\
\hline \multirow[t]{2}{*}{$\begin{array}{l}\text { Chrysaora } \\
\text { lactea }\end{array}$} & Female & 82 & Juvenile & Female & 1 & 6.04 & $\begin{array}{l}\text { Oral } \\
\text { arms }\end{array}$ & $\begin{array}{l}\text { Parasite at resting posture } \\
\text { on external surface of } \\
\text { oral arms }\end{array}$ \\
\hline & & & Larval & Undetermined & 6 & $\begin{array}{l}0.45 \text { to } \\
0.58\end{array}$ & $\begin{array}{l}\text { Gastric } \\
\text { pouches }\end{array}$ & \\
\hline $\begin{array}{l}\text { Chrysaora } \\
\text { lactea }\end{array}$ & Female & 98 & Juvenile & Female & 1 & 2.50 & $\begin{array}{l}\text { Gonadal } \\
\text { zone }\end{array}$ & \\
\hline $\begin{array}{l}\text { Chrysaora } \\
\text { lactea }\end{array}$ & Female & 89 & Larval & Undetermined & 1 & 0.80 & $\begin{array}{l}\text { Gastric } \\
\text { pouches }\end{array}$ & $\begin{array}{l}\text { Hyperiid identified as } \\
\text { Brachyscelus sp. }\end{array}$ \\
\hline $\begin{array}{l}\text { Chrysaora } \\
\text { lactea }\end{array}$ & $\begin{array}{l}\text { Not } \\
\text { sexed }\end{array}$ & $\begin{array}{l}\text { Not } \\
\text { measured }\end{array}$ & Juvenile & Male & 1 & 5.13 & & $\begin{array}{l}\text { Host collected } \\
(29 \text { November 2015) }\end{array}$ \\
\hline $\begin{array}{l}\text { Olindias } \\
\text { sambaquiensis }\end{array}$ & $\begin{array}{l}\text { Not } \\
\text { sexed }\end{array}$ & $\begin{array}{l}\text { Not } \\
\text { measured }\end{array}$ & Juvenile & Male & 1 & 4.18 & $\begin{array}{l}\text { Gonadal } \\
\text { zone }\end{array}$ & $\begin{array}{l}\text { Host used for } \\
\text { toxicological analysis }\end{array}$ \\
\hline
\end{tabular}

been suggested for some species, being found afterward as free-swimming adults in the plankton (Von Westernhagen, 1976; Sorarrain et al., 2001).

Harbison et al. (1977) observed the occurrence of two or more species of amphipods in a single medusa host, such as B. rapacoides, Brachyscelus sp., Lestrigonus schizogeneios Stebbing, 1888 and Lestrigonus sp., coexisting in the hydromedusa Aequorea sp. Apparently, Lestrigonus sp. showed some preference to consume the food captured by the host, while Brachyscelus consumed host tissues, concluding that the feeding habits of the amphipods are variable and conditioned by circumstances related to the nutrition of the host. Thus, it is possible that the feeding behavior of the amphipods is essentially opportunistic. According to Bowman et al. (1963), this type of association suggests the host tissues are not the only or main food source and nutrition for the amphipod. It is possible that the gelatinous zooplankton host act as a mobile platform from which the amphipod makes small excursions to collect food particles, including some captured by the host.

Some authors suggest that hyperiids associate with hosts only intermittently for food, transportation, protection (Vader, 1984; Dittrich, 1992), or otherwise, they would not be able to survive independently (Laval, 1980). However, others argue that they are mostly freeliving forms (Evans and Sheader, 1972), thus exist an important discussion on the degree of dependence of the hyperiids and gelatinous zooplankton hosts. The range of behavior within these associations is wide, for example, some species show a parasitoid behavior, leaving their offspring in the host, while other species have a marked and relatively prolonged parental care (Gasca and Haddock, 2004).

The distribution of the hyperiid amphipods in the host body differed in relation to their developmental stages (Laval 1980; Puente Tapia et al., 2016). Adults of Hyperia galba (Montagu, 1815) are typically found on the subumbrella and manubrium of their host Cyanea capillata (Linnaeus, 1758) where they feed on epidermal tissue (White and Bone, 1972), while the young phases of the hyperiid are found throughout the gastrovascular system because instars lack swimming appendages (Laval, 1980). In general, adult phases adopt a resting posture on the host, with only the dorsal surface of pleon in contact with the host (Madin and Harbison, 1977), as was observed in one of the individuals of the hyperiid in C. lactea in the study area.

Assuming that the distribution and abundance of the amphipods will be determined by that of the host (Harbison et al., 1977), the high abundance of C. lactea in the surveyed area (Morandini et al., 2006) could be a parameter to determine the occurrence of the hyperiid, but this aspect of its biology should be studied further based on continuous sampling. According to Lima and Valentin (2001a), some hyperiids species are often overlooked when in association with gelatinous organisms and might have a much wider distribution than it has been recorded. The frequency of their distribution and even the specificity of their hosts, serve 
as a basis for the understanding of hyperiid distribution standards, as they would have a close relationship with gelatinous animals.

It is necessary to carry out samplings at regular periodicity that allow us to understand the seasonal distribution and basic biological and ecological aspects of the associations, in order to known the dynamics of the interaction, using sampling methods appropriate for the gelatinous zooplankton or for this type of investigations, due to the fact that, conventional net sampling is not adequate to study zooplankton associations, as individuals are commonly separated due to the turbulence generated during the tows. As a consequence, gelatinous specimens are damaged and hyperiids are likely to be lost (Lima and Valentin, 2001a). The best way to record and study such associations is the collection of organisms in isolated containers by SCUBA divers (Laval, 1980) because this sampling method prevented the loss of hyperiids (Oliva et al., 2010). From net samples, identification of gelatinous zooplankton organisms is difficult because, as they are extremely fragile, they are often found semi-destroyed or severely damaged; sometimes, as the guest organisms can be expelled from the host, the opportunity to find the association is ruined (Lima and Valentin, 2001a). With the present study, we cannot prove that $B$. $c f$. rapacoides is an obligate parasite on C. lactea and O. sambaquiensis. However, there is evidence supporting the effects caused by hyperiid amphipods on gelatinous zooplankton hosts (see Harbison et al., 1977; Laval, 1980; Riascos et al., 2012;2015; Fleming et al., 2014). If hyperiid amphipods are obliged to associate with gelatinous zooplankton, then the distribution of their hosts must be the main factor determining both the horizontal and vertical distribution of them (Harbison et al., 1977).

\section{ACKNOWLEDGEMENTS}

The authors thank anonymous reviewers for their comments, which greatly improved this manuscript. This work was supported by Consejo Nacional de Investigaciones Científicas y Técnicas (AS, Proyecto de Investigaciones Plurianuales 2013-00615), Agencia Nacional de Promoción Científica y Tecnológica (AS, PICT 2013-1773), Fundação de Amparo à Pesquisa do Estado de São Paulo (ACM, FAPESP 2011/50242-5, 2013/50484-4, 2015/21007-9), and Conselho Nacional de Desenvolvimento Científico e Tecnológico, (CNPq $301039 / 2013-5,304961 / 2016-7)$. This is INIDEP contribution no. 2135, and a contribution of NP-BioMar USP.

\section{REFERENCES}

BOWMAN, T. E., MEYERS, C. D. \& HICKS, S. D. 1963. Notes on associations between Hyperiid Amphipods and Medusae in Chesapeake and Narragansett Bay and the Niantic River. Chesapeake Science, 4, 141-146.

BOUILLON, J. 1999. Hydromedusae. In: BOLTOVSKOY, D. (ed.) South Atlantic Zooplankton. Leiden: Backhuys Publishers.

BROWNE, J. G. \& KINGSFORD, M. J. 2005. A commensal relationship between the scyphozoan medusae Catostylus mosaicus and the copepod Paramacrochiron maximum. Marine Biology, 146, 1157-1168.

BRUCE, A. J. 1972. An association between a pontoniinid shrimp and a rhizostomatous scyphozoan. Crustaceana, 23, 300-302.

BUSH A. O., LAFFERTY, K. D., LOTZ, J. M. \& SHOSTAK, A. W. 1997. Parasitology meets ecology on its own terms: Margolis et al. revisited. The Journal of Parasitology, 83, 575-583.

CASTRO FILHO, B. M. 1990. Wind driven currents in the Channel of São Sebastião: winter, 1979. Boletim do Instituto Oceanográfico (São Paulo), 38, 111-132.

DICK, R. I. 1970. Hyperiidea (Crustacea: Amphipoda) Keys to South African genera and species, and a distribution list. Annals of the South African Museum, 57, 25-86.

DITTRICH, B. U. 1987. Postembryonic development of the parasitic amphipod Hyperia galba. Helgoländer Meeresuntersuchungen, 41, 217-232.

DITTRICH, B. U. 1992. Functional morphology of the mouthparts and feeding strategies of the parasitic amphipod Hyperia galba (Montagu, 1813). Sarsia, 77, 11-18.

EVANS, F. \& SHEADER, M. 1972. Host species of the hyperiid amphipod Hyperoche medusarum (Krøyer) in the North Sea. Crustaceana (Suppl), 3, 275-276.

FLEMING, N. E. C., HARROD, C., GRIFFIN, D. C., NEWTON, J. \& HOUGHTON, J. D. R. 2014. Scyphozoan jellyfish provide a short-term reproductive habitat for hyperiid amphipods in a temperate near-shore environment. Marine Ecology Progress Series, 510, 229-250.

GASCA, R. \& HADDOCK, S. H. D. 2004. Associations between gelatinous zooplankton and hyperiid amphipods (Crustacea: Peracarida) in the Gulf of California. Hydrobiologia, 530, 529535.

GASCA, R., HOOVER, R. \& HADDOOCK, S. H. D. 2015. New symbiotic associations of hyperiid amphipods (Peracarida) with gelatinous zooplankton in deep waters off California. Journal of the Marine Biological Association of the United Kingdom, 95, 503-511.

HARBISON, G. R., BIGGS, D. C. \& MADIN L. P. 1977. The associations of Amphipoda Hyperiidea with gelatinous zooplankton-II. Associations with Cnidaria, Ctenophora and Radiolaria. Deep-Sea Research, 24, 465-488.

LAVAL, P. 1980. Hyperiid amphipods as crustacean parasitoids associated with gelatinous zooplankton. Oceanography and Marine Biology, Annual Review, 18, 11-56. 
LECROY, S. E., GASCA, R., WINFIELD, I., ORTIZ, M. \& ESCOBAR-BRIONES, E. 2009. Amphipoda (Crustacea) of the Gulf of Mexico. In: FELDER, D. L. \& CAMP, D. K. (eds.) Gulf of Mexico-Origins, Waters, and Biota. Biodiversity. Volume 1. Texas: Texas A\&M University Press, College Station.

LIMA, M. C. G. \& VALENTIN, J. L. 2001a. New records of Amphipoda Hyperiidae in associations with gelatinous zooplankton. Hydrobiologia, 448, 229-235.

LIMA, M. C. G. \& VALENTIN, J. L. 2001b. Preliminary results to the holistic knowledge of the Amphipoda Hyperiidea faunal composition off the Brazilian coast. Journal of Plankton Research, 23, 469-480.

MADIN, L. P. \& HARBISON, G. R. 1977. The associations of Amphipoda Hyperiidea with gelatinous zooplankton - I. Associations with Salpidae. Deep-Sea Research, 24, 449-463.

MARTIN, J. W. \& KUCK, H. G. 1991. Faunal associates of an undescribed species of Chrysaora (Cnidaria, Scyphozoa) in the Southern California Bight, with notes on unusual occurrences of other warm water species in the area. Bulletin of the Southern California Academy of Sciences, 90, 89-101.

MARTINELLI FILHO, J. E., STAMPAR, S. N., MORANDINI, A. C. \& MOSSOLIN, E. C. 2008. Cleaner shrimp (Caridea: Palaemonidae) associated with scyphozoan jellyfish. Vie Et Milieu-Life and Environment, 58, 133-140.

METZ, P. 1967. On the relations between Hyperia galba Montagu (Amphipoda, Hyperiidae) and its host Aurelia aurita in the Isefjord area (Sjaelland, Denmark). Videnskabelige Meddelelser fra Dansk Naturhistorisk Forening, 130, 85-108.

MIANZAN, H. W. \& CORNELIUS, P. F. S. 1999. Cubomedusae and Scyphomedusae. In: BOLTOVSKOY, D. (ed.) South Atlantic zooplankton. Leiden: Backhuys Publishers.

MigotTo, A. E., MARQUES, A. C. \& FLYNN, M. N. 2001. Seasonal recruitment of hydroids (Cnidaria) on experimental panels at São Sebastião Channel, Southeastern Brazil. Bulletin of Marine Science, 68, 287-298.

MORANDINI, A. C., DA SILVEIRA, F. L. \& CORNELIUS, P. F. S. 2006. Redescription of Chrysaora lactea Eschscholtz, 1829 (Cnidaria, Scyphozoa) from the Brazilian coast, with designation of a neotype. Zootaxa, 1135, 29-48.

MOREIRA, M. G. B. S. 1961. Sobre Mastigias scintillae sp. nov. (Scyphomedusae, Rhizostomeae) das costas do Brasil. Boletim do Instituto Oceanográfico (São Paulo), 11, 5-29.

NOGUEIRA, JR. M. \& DE LOYOLA E SILVA, J. 2005. Associações entre medusas (Cnidaria) e isópodos (Crustacea) nos litorais do Paraná e Santa Catarina, Brasil. Acta Biológica Paranaense, 34, 127-138.

NOGUEIRA, JR. M., DIAZ BRIZ, L. M. \& HADDAD, M. A. 2015. Monthly and inter-annual variation of Opechona sp. (Digenea: Lepocreadiidae) parasitizing scyphomedusae off southern Brazil. Marine Biology, 162, 391-400.

OHTSUKA, S., KOIKE, K., LINDSAY, D., NISHIKAWA, J., MIYAKE, H., KAWAHARA, M. MUJIONO, N., KOMATSU, H. \& HIROMI, J. 2009. Symbionts of marine medusae and ctenophores. Plankton and Benthos Research, 4, 1-13.

PAGÈS, F. 2000. Biological associations between barnacles and jellyfish with emphasis on the ectoparasitism of Alepas pacifica (Lepadomorpha) on Diplulmaris malayensis (Scyphozoa). Journal of Natural History, 34, 2045-2056.
PHILLIPS, P. J., BURKE, W. D. \& KEENER, E. J. 1969. Observations on the trophic significance of jellyfishes in Mississippi Sound with quantitative data on the associative behavior of small fishes with medusa. Transactions of the American Fisheries Society, 98, 703-712.

PUENTE TAPIA, F.A., DÍAZ BRIZ, L. M., SCHIARITI,A., GASCA, R. \& GENZANO G. 2016. Association between Hyperoche martinezii (Amphipoda: Hyperiidae) and ctenophores from the Buenos Aires coast, Argentina (South-western Atlantic Ocean). Marine Biology Research, 12, 1078-1087.

RIASCOS, J. M., VERGARA, M., FAJARDO, J., VILLEGAS, V. \& PACHECO, A. S. 2012. The role of hyperiid parasites as a trophic link between jellyfish and fishes. Journal of Fish Biology, 81, 1868-1895.

RIASCOS, J. M., DOCMAC, F., REDDIN, C. \& HARROD, C. 2015. Trophic relationships between the large scyphomedusa Chrysaora plocamia and the parasitic amphipod Hyperia curticephala. Marine Biology, 162; 1841-1848.

SHEADER, M. \& EVANS, F. 1975. Feeding and gut structure of Parathemisto gaudichaudi (Guerin) (Amphipoda, Hyperiidea). Journal of the Marine Biological Association of the United Kingdom, 55, 641-656.

SORARRAIN, D. R., RAMIREZ, F. \& MIANZAN, H. 2001. Hyperoche medusarum (Krøyer, 1838) (Amphipoda, Hyperiidae) and Mnemiopsis mccradyi (Mayer, 1910) (Ctenophora): a new host and first record of this association for the Southwestern Atlantic. Crustaceana, 74, 407-410.

STEPHENSEN, K. 1925. Hyperiidea-Amphipoda (Part 3: Lycaeopsidae, Pronoidae, Lycaeidae, Brachyscelidae, Oxycephalidae, Parascelidae, Platyscelidae). Report on the Danish Oceanographical Expeditions 1908-10 to the Mediterranean and Adjacent Seas, 2, 151-252.

THURSTON, M. H. 1977. Depth distribution of Hyperia spinigera Bovallius, 1889 (Crustacea: Amphipoda) and medusae in the North Atlantic Ocean, with notes on the association between Hyperia and coelenterates. In: ANGEL, M. (ed.) A Voyage of Discovery. Oxford: Pergamon Press Limited.

VADER, W. 1984. Associations between amphipods (Crustacea: Amphipoda) and sea anemones (Anthozoa: Actinaria). Australian Museum Memoir, 18, 141-153.

VINOGRADOV, M. E., VOLKOV, A. F. \& EMENOVA, T. N. 1996. Hyperiid Amphipods (Amphipoda, Hyperiidea) of the World Oceans. Lebanon, Kansas, Science Publishers Inc.

VON WESTERHAGEN, H. 1976. Some aspects of the biology of the hyperiid amphipod Hyperoche medusarum. Helgoländer Wissenschaftliche Meeresuntersuchungen, 28, 43-50.

WHITE, M. G. \& BONE, D. G. 1972. The interrelationship of Hyperia galba (Crustacea, Amphipoda) and Desmonema gaudichaudi (Scyphomedusae, Semaeostomae) from the Antarctic. British Antarctic Survey Bulletin, 27, 39-49.

ZEIDLER, W. 1992. Hyperiid amphipods (Crustacea: Amphipoda: Hyperiidae) collected recently from Eastern Australian waters. Records of the Australian Museum, 44, 85-133.

ZEIDLER, W. \& DE BROYER, C. 2009. Catalogue of the Hyperiidean Amphipoda (Crustacea) of the Southern Ocean with distribution and ecological data. In: DE BROYER, C. (ed.) Census of Antarctic Marine Life: Synopsis of the Amphipoda of the Southern Ocean. Biologie: Bulletin de l'Institut Royal des Sciences Naturelles de Belgique.

ZEIDLER, W. 2016. A review of the families and genera of the superfamily PLATYSCELOIDEA Bowman \& Gruner, 1973 (Crustacea: Amphipoda: Hyperiidea), together with keys to families, genera and species. Zootaxa, 4192, 1-136. 